\section{Pengaruh Variasi Media terhadap Aktivitas Fitase Burkholderia Sp. Strain HF. 7}

\author{
Hafsan \\ Muhammad Maslan \\ Mashuri Masri \\ Laily Agustina \\ Asmuddin Natsir \\ Ahyar Ahmad
}

\begin{abstract}
Abstrak. Tanaman biji-bijian, sereal, atau kacang-kacangan yang dijadikan sebagai pakan ternak, mengandung asam fitat yang tidak dapat dicerna oleh hewan monogastrik. Asam fitat $\left(\mathrm{C}_{6} \mathrm{H}_{18} \mathrm{O}_{24} \mathrm{P}_{6}\right)$ merupakan zat antinutrisi yang mampu mengikat sekitar 80\% fosfor dalam pakan, juga mengikat protein, vitamin dan mineral $\left(\mathrm{Mg}^{++}, \mathrm{Fe}^{++}, \mathrm{Zn}^{++}, \mathrm{Mn}^{++}, \mathrm{Ca}^{++}\right)$maka, salah satu solusi untuk mengatasi masalah tersebut adalah aplikasi enzim fitase, termasuk yang dihasilkan oleh bakteri. Enzim fitase dapat menghidrolisis asam fitat pada pakan. Penelitian ini bertujuan untuk mengetahui optimalisasi produksi aktivitas fitase dari variasi media Phitate Production Media (PPM). Penelitian ini adalah menggunakan pendekatan deskriptif. Variasi sumber fitat yang digunakan: kalsium (Ca) fitat, bekatul padi, bekatul jagung, dan kedelai. Sumber nitrogen: (NH4) $2 \mathrm{SO}_{4}$, yeast extract, dan pepton. Fase pertumbuhan Burkholderia sp. Strain HF.7 ditentukan sebagai acuan untuk produksi fitase yaitu fase stasioner $62 \mathrm{jam}$ dengan nilai OD 2,060 log/sel. Produksi fitase optimum pada variasi media PPM yaitu kedelai-pepton dengan nilai kadar protein $46,5 \mathrm{mg} / \mathrm{mL}$ dan nilai aktivitas $8.20 \mathrm{U} / \mathrm{mL}$ pada kondisi $\mathrm{pH} 7$ dengan inkubasi $37^{\circ} \mathrm{C}$ selama 62 jam. Aktivtas fitase produksi PPM tanaman serealia memiliki nilai aktivtas yang lebih tinggi dibandingan media PPM Ca-fitat yang nilai aktivitasnya rendah.

Kata Kunci: Burkholderia, enzim, fitat dan fitase.
\end{abstract}

\section{Pendahuluan}

Fitat merupakan bentuk utama penyimpanan fosfor pada tanaman biji-bijian dan serelia, yaitu mencapai lebih dari $80 \%$. Asam fitat dalam kondisi alami akan membentuk ikatan yang kuat dan akan berasosiasi dengan mineral bervalensi dua $\left(\mathrm{Ca}^{2+}, \mathrm{Mg}^{2+}, \mathrm{Fe}^{2+}, \mathrm{P}^{2+}, \mathrm{Cu}^{2+}, \mathrm{Zn}^{2+}\right.$, dan $\left.\mathrm{K}^{2+}\right)$, maupun protein menjadi senyawa kompleks yang sukar larut, sehingga dapat menyebabkan gangguan metabolisme dengan menimbulkan dampak negatif pada hewan monogastrik seperti berkurangnya daya cerna terhadap protein dan mineral (Sreedevi dan Reddy, 2013).

Pada hewan monogasrtrik seperti unggas dan ikan, yang tidak menghasilkan fitase dalam saluran pencernaanya, asam fitat tidak dapat dihidrolisis. Efek lain akibat keberadaan fitat pada pakan menjadi masalah karena ketersediaan fosfor yang dapat diserap menjadi terbatas, sehingga fosfor ikut keluar bersama feses (Sajidan dkk., 2004). Sedangkan untuk memenuhi kebutuhan ternak akan fosfor, dilakukan dengan menambahkan fosfor an organik bebas ke dalam pakan yang tentu saja akan berimbas pada naiknya biaya produksi pakan. Jika dalam lingkungan peternakan pengeluaran fosfor ke lingkunga tersebut berkelanjutan, maka dapat menyebabkan pencemaran

\section{BIONATURE}

p-ISSN 1411 - 4720
e-ISSN 2654 - 5160

Abstract. Cereals and legumes used as animal feed containing phytic acid which cannot be absorbed by the digestive tract

of monogastric animals because phytic acid $\left(\mathrm{C}_{6} \mathrm{H}_{18} \mathrm{O}_{24} \mathrm{P}_{6}\right)$ is an antinutrient that binds approximately $80 \% \mathrm{P}$ in feed, also binds to proteins, vitamins and minerals

$\left(\mathrm{Mg}^{++}, \mathrm{Fe}^{++}, \mathrm{Zn}^{++}, \mathrm{Mn}^{++}, \mathrm{Ca}^{++}\right)$. Then, one option to overcome this problem is the application of phytase enzymes from various sources, including those produced by bacteria. Phytase enzymes can

hydrolyse phytic acid in the feed. This study was aimed to determine the growth phase of Burkholderia sp. HF.7 and

optimisation of production of phytase activity from variations of Phytate

Production Media (PPM) media. This

research used as a descriptive approach.

The study design used a completely randomised design (CRD) with a factorial pattern consisting of 2 factors, each variation in phytate sources: calcium (Ca) phytate, rice bran, corn bran, and soybeans. Nitrogen source: ( $\left.\mathrm{NH}_{4}\right) 2 \mathrm{SO}_{4}$, yeast extract, and peptone. Burkholderia sp. HF.7 Growth phase as a standard for phytase production is the 62-hour stationary phase with an $O D$ value of $2.060 \mathrm{log} / \mathrm{cell}$. The optimum phytase production in the variation of PPM media is soybean-peptone with a protein content value of $46.5 \mathrm{mg} / \mathrm{mL}$ and an activity value of $8.20 \mathrm{U} / \mathrm{mL}$ under conditions of $\mathrm{pH} 7$ with incubation of $37^{\circ} \mathrm{C}$ for 62 hours. So, phytase activity produced by PPM of cereal crops has a higher current value compared to PPM Ca-phytate media with low activity value.

Keywords: Burkholderia, Phytate, Phytase, enzymes.

Hafsan

Universitas Islam Negeri Alauddin Makassar Indonesia

Muhammad Maslan

Universitas Islam Negeri Alauddin Makassar Indonesia

Mashuri Masri

Universitas Islam Negeri Alauddin Makassar Indonesia

Laily Agustina

Universitas Hasanuddin Makassar Indonesia

Asmuddin Natsir

Universitas Hasanuddin Makassar Indonesia

Ahyar Ahmad

Universitas Hasanuddin Makassar Indonesia 
lingkungan karena kandungan fosfor di tanah akan terus meningkat dan bermuara pada terjadinya eutrofikasi.

Untuk mengatasi masalah penyerapan nutrisi oleh hewan monogastrik dan pencemaran lingkungan sebagai dampak dari aktifitas peternakan hewan monogastrik, maka enzim fitase menjadi salah satu jawabannya. Menurut Greiner dan Konietzny (2011), fitase termasuk kelompok enzim phosphomonoesterases yakni mio-inositol eksakisfosfat 3-fosfohidrolase (EC 3.1.3.8) dan mio-inositol eksakisfosfat 6-fosfohidrolase, (EC 3.1.3.26) dengan mampu memulai pelepasan bertahap fosfat dari asam fitat (mio-inosito $(1,2,3,4,5,6)$ hexakisphosphate). Fitase adalah enzim yang dapat memecah atau menghidrolisis senyawa fitat pada ikatan fosfoester menjadi mio-inositol dan fosfat organik (Mittal dkk., 2013).

Fitase dapat dihasilkan oleh mikrooganisme melalui induksi subtrat, tumbuhan dan jaringan tubuh ternak. Maka bakteri sebagai salah satu penghasil enzim yang potensial menjadi faktor penting dalam produksi enzim (Muthuraman dkk., 2013). Enzim yang diisolasi dari mikroorganisme memiliki beberapa keunggulan yaitu dinilai lebih menguntungkan kerena pertumbuhannya cepat dan mudah di perbayak, dapat ditumbuhkan pada subtrat yang murah, potensi produksinya tidak terbatas, potensi fitase mikroba dalam memroduski enzim dapat ditingkatkan, dan dapat dikendalikan (Hafsan, 2018). Menurut Wulandari (2015), bahwa produksi enzim dari suatu mikroorganisme sangat dipengaruhi oleh faktor internal, yaitu faktor genetik pada DNA dari masing-masing mikroorganisme. Sedangkan faktor eksternal komposisi media produksi, agitasi, suhu, dan $\mathrm{pH}$ media.

Berbagai penelitian telah melaporkan pengunaaan mikroorganisme sebagai sumber dalam produksi enzim fitase seperti Burkholderia sp., Escherichia coli, Aspergillus heteromorphus, Bacillus amyloliquefaciens, Anoxybacillys sp., Enterobacter Sakazakii, Bacillus licheniformis, Bacillus coagulans, Bacillus stearothermophillus, Penicillium Purpurogenum, Lactobacillus amylovorus, Selenomonas ruminantium, Klebsiella pneumonia, Klebsiella oxitoca, Klebsiella aerogenes dan Klebsiella terrigena (Khianngam dkk., 2011; Awad, 2012; Rebeula dkk., 2012; Hussin 2012; Kanpiengjai dkk., 2013; Sandhya dkk., 2015; Lata dkk., 2013; Wulandari , 2015; Hafsan dkk. 2018). Sebagai upaya eksplorasi sumber-sumber penghasil fitase yang potensial serta mengetahui tingkat kemampuannya dalam menghasilkan fitase, maka dilakukan penilitian mengenai produksi dan optimasi aktivitas fitase bakteri endofit asal jagung yaitu Burkholderia sp. strain HF.7 pada variasi media (sumber fitat dan sumber nitrogen) untuk mengetahui kempuan optimum enzim yang dihasilkan oleh bakteri endofit tersebut.

\section{Metode Penelitian}

\section{Prosedur Kerja}

Meliputi preparasi dan produksi, penentuan kadar protein, optimasi serta pengukuran aktivitas ekstrak kasar enzim fitase.

\section{Preparasi preparasi dan produksi ekstrak kasar enzim fitase}

Pada tahap ini diawali dengan preparasi starter kultur bakteri Burkholderia sp.strain HF.7 melalui penentuan kurva pertumbuhannya, sehingga diketahui fase untuk diinokulasikan pada media produksi. Produksi Enzim ekstrak kasar enzim fitase dilakukan dengan media PPM yang divariasikan sesuai perlakuan, yaitu dengan mengubah komposisi media PPM sumber substart fitat Ca-Fitat 0,5\% dan sumber nitrogen ammonium sulfat $\left(\mathrm{NH}_{4}\right)_{2} \mathrm{SO}_{4} \quad 0,5 \%$. Variasi yang digunakan diganti sumber substrat fitat alami tanaman pangan serealia yang mempunyai kandungan asam fitat tinggi dan banyak digunakan dalam susunan ransum pakan unggas yaitu bekatul padi, bekatul jagung, dan kedelai. Sedangkan variasi sumber nitrogen yaitu yeast extract dan pepton dengan konsentasi tetap.. 


\section{Preparasi kultur dan starter}

Pembuatan starter diawali dengan cara 5 ose isolat Burkholderia sp.strain HF.7 dari medium agar miring diinokulasikan ke dalam medium $150 \mathrm{~mL}$ LB cair baru kemudian diinkubasi pada inkubator shaker dengan diagitasi $180 \mathrm{rpm}$ pada suhu $37^{\circ} \mathrm{C}$ sampai bakteri mencapai fase stasioner yaitu 62 jam dan di simpan sebagai starter pada saat produksi fitase. Nilai OD diukur dengan interval 2 jam diawali dari 0 jam diambil $2 \mathrm{ml}$ diukur absorbansi menggunakan spektrofotometer UV-Vis pada panjang gelombang $600 \mathrm{~nm}$ sampai memperoleh satu seri OD yaitu metode turbidimetrik, blanko dibuat medium steril (Hussin, 2012; kumar dkk., 2012).

\section{Produksi Enzim ekstrak kasar enzim fitase}

Sebanyak $5 \mathrm{ml}$ starter bakteri diinokulasi pada variasi produksi (PPM) kemudian dinkubasi pada shaker incubator $180 \mathrm{rpm}$ selama 3 hari dari fase stasioner (62 jam) kurva tumbuh bakteri dengan suhu $37^{\circ} \mathrm{C}$. Kultur sel-sel bakteri yang telah diinkubasi dipisahkan dari medium dengan cara disentrifugasi $5000 \mathrm{rpm}$ selama 35 menit pada suhu $4^{\circ} \mathrm{C}$, Lalu diperoleh 2 bagian yaitu supernatan dan pelet/endapan. Supernatan yang diperoleh diukur kadar protein dan uji aktivitasnya (Hussin, 2012; kumar dkk., 2012)..

\section{Penentuan kadar protein dengan metode Bradford}

\section{Pembuatan reagen Bradford}

Ditimbang 0,1 g Coomessie Briliant Blue (CBB) G-250 kemudian dilarutkan dalam $50 \mathrm{ml}$ etanol $96 \%(\mathrm{v} / \mathrm{v})$, lalu ditambahkan $100 \mathrm{ml}$ asam fosfat 85\% (v/v). dan diencerkan mencapai 1 liter. kemudian campuran dihomogenkan sampai merata lalu disaring dengan kertas saring, penyaringan diulang beberapa kali untuk memisahkan komponen pereaksi yang berwarna biru. Pereaksi bradford harus berwarna coklat muda bening dan di simpan dalam botol gelap pada suhu rendah $4^{\circ} \mathrm{C}$ (Hussin, 2012).

\section{Pengukuran kurva standar protein}

Ditimbang 0,01 g Bovine Serum Albumin (BSA) kemudian dilarutkan dengan $10 \mathrm{ml}$ aquadest steril lalu divorteks untuk menghomogenkan sehingga diperoleh larutan induk BSA artinya sudah konsentrasi $1000 \mathrm{ppm}$. Larutan induk diencerkan diambil 0,5 $\mathrm{ml}$ dan ditambahkan $4,5 \mathrm{ml}$ aquadest steril sehingga diperoleh larutan stok BSA $100 \mathrm{ppm}$. Dari larutan stok tersebut dibuat lagi deret standar lalu ditambahkan $5 \mathrm{ml}$ pereaksi Bradford, lalu divorteks dan didiamkan pada suhu ruang selama \pm 10 menit. Protein diukur absorbansinya pada spektrofotometer panjang gelombang $595 \mathrm{~nm}$.

\section{Pengukuran sampel}

Sampel diambil 0,1 ml ekstrak kasar enzim dan ditambahkan $5 \mathrm{ml}$ reagen Bradford, lalu divortex dan didiamkan \pm 10 menit. Absorbansi larutan sampel protein diukur pada panjang gelombang $595 \mathrm{~nm}$ dan dibuat blanko dari $0 \mathrm{ppm}$ standar protein. Dengan persamaan metematik dari kurva standar protein, akan didapatkan kadar protein terlarut yang terkandung dalam larutan ekstrak kasar enzim (supernatant). 


\section{Penentuan aktivitas fitase dengan kadar fosfat}

\section{Pembuatan reagen warna besi sulfat-molibdat biru}

1) Ditimbang $7,5 \mathrm{~g}$ amonium molybdat dilartukan dalam $400 \mathrm{ml}$ aquadest steril, kemudian dihomogenkan dan perlahan-lahan ditambahkan $22 \mathrm{ml}$ asam sulfat $\left(\mathrm{H}_{2} \mathrm{SO}_{4}\right)$, lalu diencerkan mencapai $500 \mathrm{ml}$ dengan aquadest steril sehingga terbentuk warnanya hijau (stok amonium molybdat). 2) ditimbang 2,7 $\mathrm{g} \mathrm{FeSO}_{4}$ dilarutkan dalam $100 \mathrm{ml}$ aquadest steril sehingga terbentuk warna kuning (Stok Besi Sulfat). Masing larutan di simpan pada botol gelap dan suhu rendah $4{ }^{\circ} \mathrm{C}$ sampai 1 bulan. Pembuatan pereaksi warna molybdat kedua larutan dicampur amonium molibdat dan besi sulfat dengan perbandingan 4:1 (Hussin, 2012; Kumar dkk, 2012).

\section{Pembuatan kurva standar fosfat}

Ditimbang 0,3834 g kalium dihidrogen fosfat $\left(\mathrm{KH}_{2} \mathrm{PO}_{4}\right)$ di larutkan dalam $100 \mathrm{ml}$ aquadest steri sebagai larutan induk dengan konsentrasinya 1000 ppm. Kemudian encerkan lagi dalam 100 kali. Jadi $10 \mathrm{ml}$ larutan induk diencerkan dengan aquadest steril mencapai $100 \mathrm{ml}$ sebagai larutan standar dengan konsentrasi 10 ppm mengandung 0,03834 g. Kemudian dibuat deret larutan fosfat standar lalu ditambahkan 6,25 pereaksi warna molybdat. Larutan dihomogenkan dan didiamkan selama \pm 10 menit pada suhu ruang lalu diencerkan dengan aquades steril sampai volume mencapai $25 \mathrm{ml}$. kemudian ukur absorbansi pada spektrofotometer dengan panjang gelombang $700 \mathrm{~nm}$.

\section{Pengukuran aktivitas ekstrak kasar enzim fitase}

Sampel diambil 0,15 ml supernatan inkubasi dengan substrat 0,6 ml larutan buffer Tris-HCl 0,1 $\mathrm{M} \mathrm{pH} 7$ yang mengandung $2 \mathrm{mM}$ Ca-Fitat dan $2 \mathrm{mM} \mathrm{CaCl}_{2}$ pada suhu $37^{\circ} \mathrm{C}$ selama \pm 30 menit. Setelah diinkubasi reaksi dihentikan dengan ditambahkan 0,75 TCA 5\%, dan terakhir ditambahkan 1,5 ml reagent warna molybdat. kemudian diukur absorbansinya menggunakan spektofotometer UV-Vis pada panjang gelombang $700 \mathrm{~nm}$ (Hussin, 2102).

\section{Optimasi produksi aktivitas ekstrak}

Dinkubasi pada inkubator shaker diagitasi $180 \mathrm{rpm}$ dengan suhun $37^{\circ} \mathrm{C}$ selama fase stasioner kurva tumbuh bakteri (62jam). Pengolahan data penilitian disajikan dalam bentuk tabel dan grafik yang dianalisa secara deskristif. Aktivitas fitase dinyatakan Satu unit enzim fitase (UI) didefanisikan sebagai jumlah enzim yang dibutuhkan untuk membevaskan 1 mikromol $(\mu \mathrm{M})$ fosfor anorganik (Pi) per menit pada kondisi pengujian. Pengukuran aktivtas fitase dan kadar protein ditentukan dengan cara mesubstitusi data absorban ke dalam persamaan regresi linear dari kurva larutan standar. Kurva larutan standar didasarkan pada data larutan standar protein albumin (BSA) dengan panjang gelombang $595 \mathrm{~nm}$ dan data larutan standar fosfat $\left(\mathrm{KH}_{2} \mathrm{PO}_{4}\right)$ dengan panjang gelombang $700 \mathrm{~nm} .15$

\section{Hasil Penelitian}

Burkholderia sp. strain HF.7 merupakan bakteri yang diisolasi dari tanaman jagung (Zea mays) bagian akar dapat menghasilkan enzim fitase. Tahap awal yang dilakukan adalah kurva pertumbuhan pada sistem tertutup dengan mengukur kerapatan optik OD (Optical density) kultur 
murni bakteri Burkholderia sp. strain HF.7 yang akan digunakan untuk produksi enzim Fitase. Adapun kurva pertumbuhan yang diperoleh sebagaimana grafik berikut:

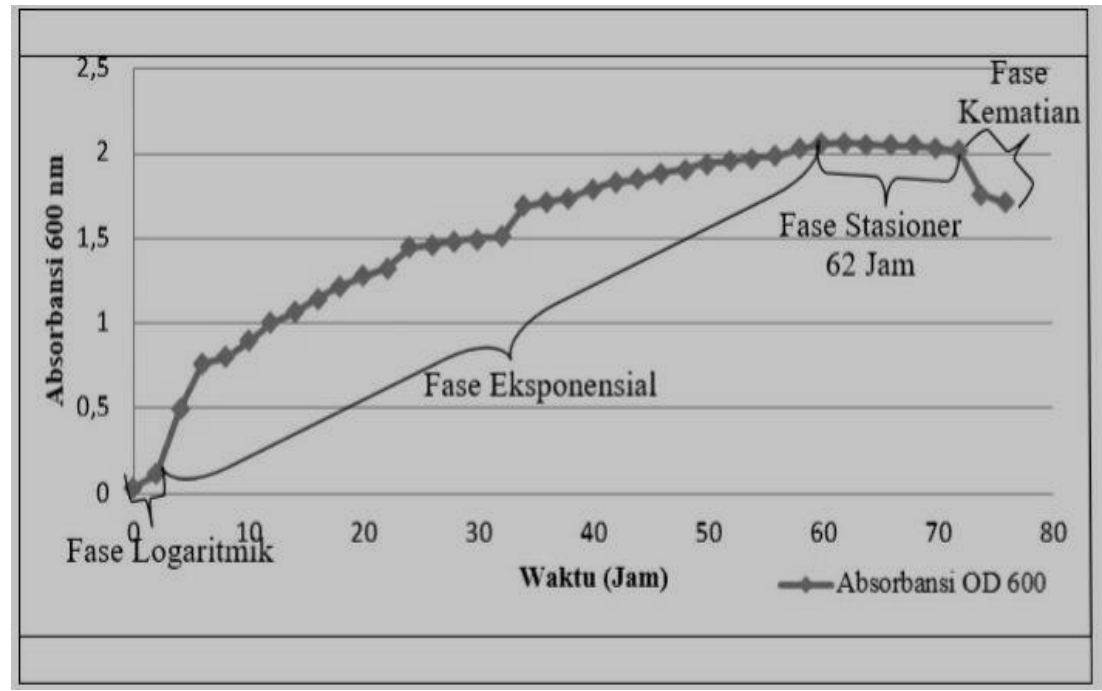

\section{Gambar 1. Kurva Tumbuh Burkholderia sp HF.7 pada Kultur Tertutup}

Sebagaimana kurva pertumbuhan pada gambar tersebut, fase pertumbuhan bakteri secara umum terbagi atas 4 fase yaitu fase lag, fase logaritmik, fase stasioner dan fase kematian. Hasil pengamatan menunjukkan fase lag atau fase tenggang terjadi pada 0 jam sampai 2 jam ini, yakni pertumbuhan sel bakteri Burkholderia sp. Strain HF.7 sedikit karena bakteri tersebut masih dalam tahap beradaptasi pada medium baru sehingga nilai hasil OD kecil 0,031 log/sel sampai 0,114 log/sel (Volk and Wheeler 1993 and Pratiwi, 2008). Fase logaritmik terjadi setelah melewati jam 2 sampai dengan 62 jam, sel bakteri dari awal lambat dan sedikit lalu meningkat lebih cepat dan lebih besar, karena masih perlu untuk tumbuh dan berdapatasi pada medium baru. Hal ini dibuktikan nilai OD terus meningkat dari 0,488 log/sel menjadi 2,060 log/sel. Petumbuhan bakteri terus berlangsung maka sel bakteri telah mencapai pembelahan dan petumbuhan paling tinggi dan nilai konstan atau mengalami keseimbangan antara jumlah sel bakteri membelah sama dengan jumlah sel bakteri yang mati,kemudian mengalami pergantian sel sehingga terdapat kehilangan sel yang lambat. Hal ini dibuktikan dengan awal fase stasioners (tetap) yakni nilai OD dari jam 62 nilai 2,060 log/sel, kemudian mengalami penurunan dijam 72 dengan nilai 2,007 log/sel.

Sel bakteri yang terus membelah sehingga terjadi mutasi dan mengalami lisis telah memasuki fase kematian dari jam 72 sampai jam 76 nilai OD terus menurun artinya jumlah sel bakteri Burkholderia sp. Strain HF.7 mati meningkat karena ketersediaan nutrisi berkurang dan akumulasi produk buangan yang bersifat toksik atau racun dengan nilai yang dapat dari 2,007 $\log /$ sel menjadi 1,702 log/sel. Fase ini terjadi akumulasi toksik, nutrisi dalam medium sudah habis dan energi cadangan dalam sel habis sehingga banyak sel yang mati. Jumlah sel yang mati bertambah secara eksponensial. Dalam fase ini sel hidup hanya dapat bertahan untuk sementara, waktu generasi sangat lama bahkan tidak ada sama sekali.

Awal fase stasioner dijadikan waktu inkbuasi dan diremajakan Burkholderia sp. strain HF.7 sebagai starter pada saat produksi fitase, maka waktu inkubasi yang tepat dapat dilihat gambar 1 yaitu di jam 62 jam dengan nilai OD 2,060 log/sel, karena waktu tersebut pertumbuhan sel bakteri terbentuk dengan laju konstan dan belum terjadi akumulasi produk buangan yang bersifat toksik. Maka enzim fitase didapatkan enzim dari hasil metabolit sekunder Burkholderia sp. Strain HF.7 yaitu ekstraseluler (enzim kasar fitase). Hussin (2012), mengatakan bahwa awal fase stasioner waktu yang tepat untuk mengisolasi enzim yang dihasilkan bakteri. Sedangkan 
Greiner dan Konietzny (2011) menyampaikan bahwa sintesis fitase dari mikroorganisme adalah pada fase awal stasioner mencapai puncak produksi pada akhir fase eksponensial. Demikian halnya menurut Kumar dan Sushma (201) bahwa produksi ekstrak enzim dalam tahap akhir dari pertumbuhan eksponensial, yaitu awal fase stasioner. Setelah mengetahui fase pertumbuhan bakteri yang digunakan, dilakukan produksi fitase dengan variasi media PPM (Phytase Production Medium) berdasarkan sumber fitat dan sumber nitrogen yang berbeda. Tujuan optimalisasi untuk mengetahui komposisi media yang dapat memicu produksi fitase dengan aktivitas yang tinggi.

Upaya optimalisasi produksi fitase melalui variasi sumber fitat dan nitrogen yang dilakukan, menunjukkan nilai aktivitas fitase dari tertinggi yaitu kedelai-pepton $8.20 \mathrm{U} / \mathrm{mL}$ kemudian disusul jagung- $\left(\mathrm{NH}_{4}\right)_{2} \mathrm{SO}_{4} 7,20 \mathrm{U} / \mathrm{mL}$ kedelai - yeast exstract $6.86 \mathrm{U} / \mathrm{mL}$, kedelai$\left(\mathrm{NH}_{4}\right)_{2} \mathrm{SO}_{4} 6.56 \mathrm{U} / \mathrm{mL}$, padi-pepton $6.81 \mathrm{U} / \mathrm{mL}$, padi-yeast $6.73 \mathrm{U} / \mathrm{mL}$, jagung-yeast $6.70 \mathrm{U} / \mathrm{mL}$ jagung-pepton $6.66 \mathrm{U} / \mathrm{mL}$, padi- $(\mathrm{NH} 4)_{2} \mathrm{SO}_{4} 6.64 \mathrm{U} / \mathrm{mL}$, Ca fitat-(NH4) ${ }_{2} \mathrm{SO}_{4} 6.58 \mathrm{U} / \mathrm{mL}$, kedelai$(\mathrm{NH} 4)_{2} \mathrm{SO}_{4} 6.56 \mathrm{U} / \mathrm{mL}$, Ca fitat-Yeast Exstract $6.54 \mathrm{U} / \mathrm{mL}$, dan ca fitat-pepton $6.54 \mathrm{U} / \mathrm{mL}$. Hasil pengukuran tersebut sebagaimana grafik pada gambar 2 mengindikasikan nilai aktivitas optimum dalam produksi fitase dihasilkan dari media PPM dengan kombinasi komposisi sumber fitat dan nitrogen berupa kedelai-pepton dengan aktivitas $8.20 \mathrm{U} / \mathrm{mL}$. Kanpiengjai dkk (2013) yang telah menggunakan dedak padi dan ekstrak tepung kedelai dalam penelitiannya untuk memaksimalkan produksi fitase strain bakteri tanah PH01, menjelaskan bahwa hubungan antara asam fitat dan sumber nitrogen, dimana substrat kedelai memiliki kandungan asam fitat yang tinggi juga mengandung protein yang tinggi dan kaya dengan nutrisi atau mineral lainnya sehingga nutrisi pertumbuhan bakteri dapat terpenuhi untuk produksi fitase yang maksimum dibanding sumber fitat dan nitrogen lainnya. Kadungan asam fitat pada kedelai yang tinggi, yaitu 1,4\% kemudian, jagung 0,9\%, lalu padi 0,89\%, menjadi faktor kedelai sebagai sumber fitat yang baik untuk menginduksi produksi fitase oleh bakteri. Selain itu kedelai memiliki kandungan protein tinggi dibandingkan dengan jagung dan dedak padi sehingga dapat menjadi sumber nutrisi berupa protein.

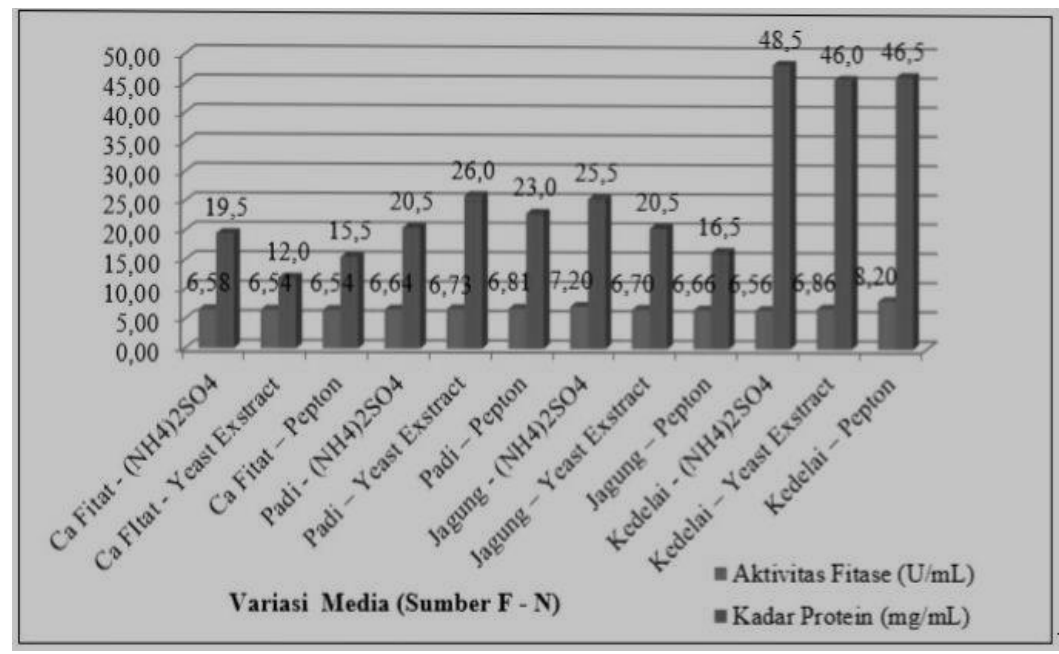

\section{Gambar 2. Aktivitas Fitase dan Kadar Protein Burkholderia sp. strain HF.7 terhadap Variasi Media Berdasarkan Sumber Fitat dan Sumber Nitrogen.}

Bakteri dapat menghasilkan lebih dari 1 jenis enzim atau beberapa enzim. Seperti halnya pada produksi fitase oleh bakteri Burkholderia sp. strain HF.7 yang masih berupa ekstrak kasar, masih banyak senyawa pengotor didalamnya dan enzim lainnya. Hasil yang didapatkan bahwa nilai kadar protein dengan aktivtas fitase pada media produksi PPM, antara tingginya konsentrasi protein enzim tidak berbanding lurus terhadap aktivitas fitasenya. Misalkan pada variasi media PPM Kedelai bahwa kedelai-pepton memiliki nilai kadar protein rendah, namun memiliki nilai aktivitas tinggi, karena memeiliki konsentrasi enzim fitase tinggi. Sedangkan jika dibandingakan 
media produksi PPM kedelai-yeast dan kedelai- $\left(\mathrm{NH}_{4}\right)_{2} \mathrm{SO}_{4}$ yang memiliki nilai kadar protein tinggi, tetapi aktivitasnya rendah hal ini dikerenakan konsentrasi enzim fitasenya rendah, demikian halnya dengan media PPM lainnya.

Berdasarkan hasil penelitian diperoleh nilai kadar protein enzim tertinggi berturutturut kedelai-pepton $46.5 \mathrm{mg} / \mathrm{mL}$, kedelai-yeast $46.0 \mathrm{mg} / \mathrm{mL}$, dan kedelai- $\left(\mathrm{NH}_{4}\right)_{2} \mathrm{SO}_{4} 48.5$ $\mathrm{mg} / \mathrm{mL}$, padi - yeast Exstract sebanyak $26.0 \mathrm{mg} / \mathrm{mL}$, Jagung - $\left(\mathrm{NH}_{4}\right)_{2} \mathrm{SO}_{4}$ sebanyak $25.5 \mathrm{mg} / \mathrm{mL}$, padi - pepton sebanyak $23.0 \mathrm{mg} / \mathrm{mL}$, padi - $\left(\mathrm{NH}_{4}\right)_{2} \mathrm{SO}_{4}$ sebanyak $20.5 \mathrm{mg} / \mathrm{mL}$, jagung - yeast exstract sebanyak $20.5 \mathrm{mg} / \mathrm{mL}$, Ca fitat - $\left(\mathrm{NH}_{4}\right)_{2} \mathrm{SO}_{4}$ sebanyak $19.5 \mathrm{mg} / \mathrm{mL}$, jagung - pepton sebanyak $16.5 \mathrm{mg} / \mathrm{mL}$, Ca fitat - pepton sebanyak $15.5 \mathrm{mg} / \mathrm{mL}$, dan Ca fitat - yeast exstract sebanyak $12.0 \mathrm{mg} / \mathrm{mL}$. maka dapat disimpulkan bahwa produksi fitase dari PPM sereal (kedelai, bekatul padi, jagung) memiliki kadar protein tinggi dibandingan fitase dari PPM Ca-fitat yang miliki nilai kadar protein rendah.Dalam variasi media PPM juga memiliki kandungan dan komposisi yang lengkap dan dimanfaat oleh bakteri Burkholderia sp. strain HF.7 baik dari sumber nitrogen dan fosfat atau sumber nutrisi lainnya.

Pada kombinasi nilai kadar protein dengan aktivitas fitase yang dihasilkan bahwa media PPM pangan (kedelai, jagung dan, bekatul padi) memiliki nilai lebih tinggi dibandingkan dengan produksi fitase PPM Ca-Fitat. Maka pada penelitian ini produksi fitase dari tanaman pangan serealia sebagai alternatif substrat asam fitat yang harga murah dan mudah dijangkau, sedangkan jika produksi fitase mengandalkan substrat Ca-fitat, selain harganya mahal juga langka dipasaran.

Beberapa penelitian produksi fitase dari tanaman pangan serealia dengan berbagai jenis strain bakteri telah banyak dilaporkan, salah satunya menurut Kanpiengjai dkk.,. (2013) yang melaporkan bahwa pengaruh sumber substrat dari bahan pertanian untuk produksi fitase dari Pseudomomas sp, menunjukkan substrat bekatul+ragi yang memiliki jumlah maksimum produksi fitase dengan aktivitas $0,891 \mathrm{U} / \mathrm{mL}$ dibandingkan dengan lainnya bekatul padi $0,551 \mathrm{U} / \mathrm{mL}$, bekatul jagung $0,639 \mathrm{U} / \mathrm{mL}$, dan gandum $0,610 \mathrm{U} / \mathrm{mL}$ ). Waktu optimum produksi fitase yaitu 72 jam. Amonium sulfat, Sukrosa dan suhu $37^{\circ} \mathrm{C}$ yang diamati sebagai sumber nitrogen, karbon dan suhu inkubasi yang terbaik untuk produksi fitase lebih tinggi. Produksi fitase dari substrat pertanian memberikan banyak keuntungan terutama mengurangi biaya produksi.

Menurut Khianngam (2011) bahwa Bacillus amyloliquefarciens digunakan sebagai produksi enzim fitase dari berbagai sumber substrat pertanian bahwa Na-fitat adalah susbstrat terbaik untuk produksi aktivitas fitatse, tapi harganya mahal. Dedak padi, dedak gandum, kulit kacang, biji sisal, biji kacang tanah, biji sorgum, biji jagung, dan biji bunga matahari merupakan substrat alternatif yang dapat digunakan sebagai pakan ternak dengan biaya rendah. makanan sisal dan biji kacang tanah tidak ada aktivitas. Hasil penelitian menunjukkan bahwa penggunaan dedak gandum $(21,833 \pm 0,837 \mathrm{U} / \mathrm{mL})$ dan biji sorgum $(21,185 \pm 0,000 \mathrm{U} / \mathrm{mL})$ menghasilkan aktivitas enzim yang lebih baik dari pada Na-fitat $(20,397 \pm 0,478 \mathrm{U} / \mathrm{mL})$. kemudian, penggunaan dedak padi $(18,256 \pm 0.000 \mathrm{U} / \mathrm{mL})$ sebagai substrat menunjukkan produksi fitase sama dengan aktivitas Na-phytase. Sedangkan biji jagung $(1.465 \pm 0,239 \mathrm{U} / \mathrm{mL})$ dan biji bunga matahari $(5,156 \pm 0,120 \mathrm{U} / \mathrm{mL})$ memiliki nilai aktivitas rendah dari Na-fitat.

Menurut Muthuraman dkk. (2013) bahwa produksi fitase maksimum dari Pseudomonas flurescens menggunakan dedak gandum, yeast ekstrak, kalium dighidrogen fosfat sebagai sumber karbon, nitrogen dan fosfat pada pH 6, selama 3 hari dengan aktivtas enzim $32.94 \mathrm{U} / \mathrm{mL}$ pada kondisi yang optimum. Menurut Hussin dkk., (2012) bahwa produksi fitase optimum menggunakan sumber fitat 13,6\% bekatul padi dengan aktivitas 11,511 U/mL. Menurut Shumizu (1992) bahwa memproduksi fitase dari kedelai oleh Bacillus suhtilis (natto) N-7 dengan glutamate dan sukrosa sebagai sumber nitrogen dan carbon, kemudian hasil hidrolisis fitase dari pada asam fitat biji-bijian yang memiliki nilai aktivitas yaitu kedelai 7,84 $\mu \mathrm{M} / \mathrm{mL}$ dan dedak padi $2,77 \mu \mathrm{M} / \mathrm{mL}$. 


\section{Kesimpulan}

Fase stasioner pada kurva pertumbuhan Burkholderia sp. strain HF.7 sebagai acuan produksi enzim fitase yaitu yaitu pada 62 jam dengan nilai $\mathrm{OD}_{600} 2,060 \mathrm{log} / \mathrm{sel}$. Produksi fitase dari variasi Phytase Production Medium (PPM) sumber fitat dan sumber nitrogen oleh

Burkholderia sp. Strain HF.7 bahwa aktivitas fitase media PPM (kedelai, padi dan jagung) memiliki nilai lebih tinggi dari pada produksi media PPM Ca-fitat yang lebih rendah nilai aktivitasnya. Maka didapat media produksi fitase (PPM) yang optimum adalah kedelai-pepton dengan kadar protein $46.5 \mathrm{mg} / \mathrm{mL}$ dan aktivtas fitase tertinggi $8.20 \mathrm{U} / \mathrm{mL}$ pada kondisi tertentu.

\section{Referensi}

Awad, Ghada, E. A. (2012). Optimization Of Phytase Production By Penicillium Purpurogenum GE1 Under Solid Sate Fermentation By Using Box-Bahnken Design. King Saudi Univesity. Saudi Journal of Biological Sciences, 2 (1).

Greiner, R., and Konietzny, U. (2011). Phytase. Biochemistry, enzymology and characteristics relevant to animal feed use. In: M.R. Bedford and G.G. Partridge (eds). Enzymes in farm Animal Nutrion 2nd Ed.USA: CABI Pub, 2011, 96-128.

Hafsan. (2018). The Potential of Endophyte Bacteria Isolated From Zea Mays L. as Phytase Producers. JPAM, 12 (3), 1277-1280.

Hussin, A. S. M. (2012). Optimization Of Cultivation Condition For The Production Of PhytaseDegrading Enzumes By Enterobacter Sakazakii ASUIA279 Isolated Form Malaysia Maize Root. Malaysia. journal of Biotechnology and Biodiversity, 3 (2)

Kanpiengjai, Apinun., K. Unban., R. Prathanaphon., \& C. Khanongnuch. (2013). Optimal Medium and Conditions for Phytase Production by Thermophilic bacterium, Anoxybacillys sp. MHW14. Food and Applied Bioscience Journal, 1 (3).

Khianngam S., Y. Pootaeng, A. Sonloy, J. Kajern-aroonki, \& S. Tanasupawai. (2011). Caharacterization and Comparasion of Phytase Production by Bacillus and Paenibacillus strain from Thai Soils. Thailand. Malaysian Journal of Microbiologi, 2 (2).

Kumar, M. \& Sushma. (2011). Optimization of production media of Novel Phytase from Aspergillus niger Using Wheat Bran Waste. India. International Journal of Sciences and Research (IJSR), 3(1).

Kumar, D., J. Mukesh, K. C. P. Rajamanikandan., K. S. Shamna., M. D. Balakumaran \& P. T. Kalaichelvan. (2012). Extracelluler Production Of Phytase By A Native Bacillus Subtilis Strain. India: Sacholars Research Library: Annals of Biological Research. 3 (2).

Lata, S., S Rastogi, A. K. \& M. Imran. (2013). Optimization of culture conditional for the production of phytase from Aspergillus heteromorphus MTCC 10685. India: international Journal of Advanced Biotechnology and Research, 4 (2). 
Mittal, A., G. Singh, V. Goyal, A. Yadav, K. R. Aneja, S. K. Guatam, \& N. K. Aggarwal. (2013). Isolation And Biochemical Characterization Of Acido-Thermophilic Extracelluelar Phytase Producing Bacterial Strain For Potential Application In Poultry Feed. Jundishapur Journal of microbiology, 4 (4).

Muthuraman, M. Sundaram \& A. Tungala, \& K. A. Narayanan. (2013). Isolation Of Phytase Producing Bacteria From Poultry Faeces And Optimization Of Culuture Conditions For Enhanced Phytase Production. Academis Science. IJPPS, 5 (2).

Rebeula, M., T. Selvamohan., \& V. Ramadas. (2012). Optimazation of Phytase Production by Pseodomonas sp. Isolated from Poultry Faces. India: International Journal of Modern Engineering Research, (3).

Sajidan, A. Ratriyanto dan A.M.P. Nuhriawangsa. (2004). Pengaruh Bakteri Penghasil Fitase pada Pakan Campuran Wheat Pollard terhadap Perfoman Ayam Broiler. Buletin Peternakan. Yogyakart. Fakultas Peternakan UGM, 28 (3).

Sandhya, A., A. Sridevi., P. Suvarnalatha Devi., \& G. Narasimha. (2015). Production and Optimization Of Phytase By Aspergillus niger. India: Scholar Research Library, Der Pharmacia Lettre, 7 (12).

Wulandari, R., Sajidan, \& Suranto. (2015). Analisis Gen 16s rRNA pada Bakteri Penghasil Enzim Fitase. Surakarta. Sikripsi Program Pasca Sarjana Universitas Sebelah Maret Surakarta.

\begin{tabular}{|l|l|}
\hline Hafsan & $\begin{array}{l}\text { Prodi Biologi, Fakuiltas Sains dan Teknologi, Universitas Islam } \\
\text { Negeri Alauddin Makassar } \\
\text { E-mail: hafsan.bio@uin-alauddin.ac.id }\end{array}$ \\
\hline Muhammad Maslan & $\begin{array}{l}\text { Prodi Biologi, Fakuiltas Sains dan Teknologi, Universitas Islam } \\
\text { Negeri Alauddin Makassar } \\
\text { E-mail: } \underline{\text { maslan@uin-alauddin.ac.id }}\end{array}$ \\
\hline Mashuri Masri & $\begin{array}{l}\text { Prodi Biologi, Fakultas Sains dan Teknologi, Universitas Islam } \\
\text { Negeri Alauddin Makassar } \\
\text { E-mail: hafsan.bio@uin-alauddin.ac.id }\end{array}$ \\
\hline Laily Agustina & $\begin{array}{l}\text { Prodi Nutrisi dan Teknologi pakan, Fakultas Peternakan, } \\
\text { Universitas Hasanuddin Makassar } \\
\text { E-mail: laily.agustina@gmail.com }\end{array}$ \\
\hline Asmuddin Natsir & $\begin{array}{l}\text { Prodi Nutrisi dan Teknologi pakan, Fakultas Peternakan, } \\
\text { Universitas Hasanuddin Makassar } \\
\text { E-mail: asmuddin natsir@unhas.ac.id }\end{array}$ \\
\hline Ahyar Ahmad & $\begin{array}{l}\text { Prodi Kimia, Fakultas Peternakan, Universitas Hasanuddin } \\
\text { Makassar } \\
\text { E-mail: ahyarahmad@gmail.com }\end{array}$ \\
\hline
\end{tabular}

